\title{
Effects of commonly used chemical fertilizers on development of free-living stages of Haemonchus contortus in experimentally infected pasture
}

Tapas Kumar Roul ${ }^{1}$, Mitra Rajan Panda ${ }^{1}$, Bijayendranath Mohanty ${ }^{1}$, Kautuk Kumar Sardar ${ }^{2}$, Manaswini Dehuri ${ }^{1}$, Ananta Hembram ${ }^{1}$ and Trilochan Mohapatra ${ }^{1}$

1. Department of Veterinary Parasitology, College of Veterinary Science \& Animal Husbandry, Orissa University of Agriculture \& Technology, Bhubaneswar - 751 003, Odisha, India; 2. Department of Veterinary Pharmacology \& Toxicology, College of Veterinary Science \& Animal Husbandry, Orissa University of Agriculture \& Technology, Bhubaneswar - 751 003, Odisha, India.

Corresponding author: Bijayendranath Mohanty, e-mail: bijayendranath@gmail.com

Co-authors: TKR: tapasroul51@gmail.com, MRP: profmrp@rediffmail.com, KKS: kksardar@gmail.com, MD: manaswini2003@yahoo.com, AH: ananta.ouat06@gmail.com,TM: trilochan72ovc@gmail.com Received: 14-03-2017, Accepted: 20-05-2017, Published online: 10-07-2017

doi: 10.14202/vetworld.2017.764-768 How to cite this article: Roul TK, Panda MR, Mohanty B, Sardar KK, Dehuri M, Hembram A, Mohapatra T (2017) Effects of commonly used chemical fertilizers on development of free-living stages of Haemonchus contortus in experimentally infected pasture, Veterinary World, 10(7): 764-768.

\begin{abstract}
Aim: The effects of N-P-K fertilizers in the form of urea, single super phosphate and muriate of potash on development of free-living stages of Haemonchus contortus were studied.

Materials and Methods: Five parasite free experimental plots of $1 \mathrm{~m} \times 1 \mathrm{~m}$ area, each of paddy leaves (15-day-old) and an equal number of Cynodon dactylon grass were infested with about $10 \times 10^{4}$ eggs $/ \mathrm{ml}$ phosphate buffer saline along with the application of the calculated amount of fertilizers solution. On the $10^{\text {th }}$ day of posttreatment, the pasture was cut, processed, larvae recovered by Baermann method and counted, which was expressed as number of $\mathrm{L}_{3}$ per $\mathrm{kg}$ dry matter (DM) of pasture.

Results: The average recovered population of $\mathrm{L}_{3}$ of $H$. contortus per $\mathrm{kg}$ DM varied significantly $(\mathrm{p}<0.05)$ between the paddy leaves (5933.57 \pm 22.718$)$ and Cynodon grass $(4861.00 \pm 22.718)$. When different doses of chemical fertilizer and their impact on different pasture were analyzed for control (T-1, 0-0-0 kg/ha N-P-K), the mean $\mathrm{L}_{3}$ recovery per $\mathrm{kg}$ DM of paddy (19512.7 \pm 50.80$)$ was more than that of Cynodon grass (16540.9 \pm 50.80$)$. Larvae recovery per kg DM for different pastures under treatment were in decreasing order as follows: T-2 of paddy $(6981.33 \pm 50.80,35.77 \%)$, T-2 of Cynodon $(5545.38 \pm 50.80,33.52 \%)$, T-3 of paddy $(317378 \pm 50.80,16.26 \%)$, and T-3 of Cynodon $(2218.72 \pm 50.80,13.41 \%)$ which showed significant difference $(\mathrm{p}<0.05)$ among the treatments. In T-4 (paddy) and T-5 (Cynodon), the average number of recovery of larvae was nil implying no significant variation $(\mathrm{p}>0.05)$.
\end{abstract}

Conclusion: This study shown that when N-P-K fertilizers administered at recommended level, significantly reduced larval translation of $H$. contortus minimizing pasture infectivity for the free range grazing animals.

Keywords: Haemonchus contortus, larva, N-P-K fertilizer, pasture.

\section{Introduction}

One of the major constraints to the profitable livestock farming is the widespread worm infection worldwide [1]. In livestock, gastrointestinal nematode infections cause a heavy economic loss in terms of ill health, low productivity, morbidity and mortality [2,3]. The situation is challenging in tropics and subtropics due to prevailing of warm and wet climates throughout the year $[4,5]$. Here, the pasture provides a conducive environment for development, i.e., deposition of eggs, hatching, development of larva, and dissemination of infective larvae of gastrointestinal nematodes to the definitive hosts [6]. Surveys indicated that pasture

Copyright: Roul, et al. Open Access. This article is distributed under the terms of the Creative Commons Attribution 4.0 International License (http://creativecommons.org/licenses/by/4.0/), which permits unrestricted use, distribution, and reproduction in any medium, provided you give appropriate credit to the original author(s) and the source, provide a link to the Creative Commons license, and indicate if changes were made. The Creative Commons Public Domain Dedication waiver (http://creativecommons.org/ publicdomain/zero/1.0/) applies to the data made available in this article, unless otherwise stated. is the storehouse of parasites mostly Haemonchus contortus, Trichostrongylus spp., Oesophagostomum spp., Cooperia spp., and Mecistocirrus spp. [7]. Among these, $H$. contortus is the most important gastrointestinal nematode parasite of small ruminants for its wide distribution and high pathogenicity [8]. It inflicts heavy blood loss leading to anemia, anorexia, loss of condition, stunted growth, hypoproteinemia, and even death of animals. In the absence of specific vaccines against many gastrointestinal nematodes due to antigen complexity as well as parasitic immunity, not properly understood, use of anthelmintic has been the main method of their control since long. This has resulted in emergence of anthelmintic resistance in target worms affecting the success rate of reducing the worm burden in the animals [9].

In this context, alternative control methods are being employed and evaluated throughout the world to find a suitable alternative to anthelmintics. In addition, anthelmintics have no distinct role in killing 
the infective larvae of nematodes present in pasture. Therefore, other chemical agents that can be applied on pasture need to be evaluated for their possible effect, if any, on the pasture larvae.

This experiment was carried out with an aim to study the effect of some commonly used chemical fertilizers on free-living stages of $H$. contortus which is widely prevalent and important from pathogenic point of view. Inadequacy of available literature relating to this type of study was also another motivating factor to undertake this study. Hence, this investigation was attempted to assess whether the N-P-K fertilizers, that are commonly used to fortify the soil to produce more fodder, have any larvicidal effect on the free-living stages of $H$. contortus in pasture.

\section{Materials and Methods}

\section{Ethical approval}

This experiment involved no use of live animals and was conducted in accordance with the guidelines provided by the Institutional Ethical Committee and also complies with the country's laws.

\section{Study site}

In vivo study was conducted for 1 year inside the experimental farm area, Department of Agronomy, Orissa University of Agriculture and Technology

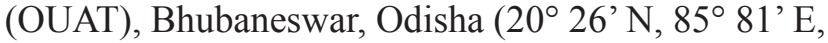
and $34 \mathrm{~m}$ above mean sea level). It has a hot humid climate with mean annual rainfall of $1482 \mathrm{~mm}$. The annual mean maximum and minimum temperature of the area were 31.5 and $22.3^{\circ} \mathrm{C}$, respectively. The facilities available in the Department of Veterinary Parasitology and other Departments of College of Veterinary Science and Animal Husbandry, Bhubaneswar, Odisha, were utilized to carry out the parasitological studies. Adult $H$. contortus parasites were collected from gastrointestinal tracts of goats slaughtered at local abattoirs of Bhubaneswar, Odisha.

\section{Collection of $\boldsymbol{H}$. contortus eggs}

Abomasum of freshly slaughtered goats was collected in thermo cool boxes from a local abattoir and brought to the Department of Veterinary Parasitology. The adult female $H$. contortus distinguished from their barber's pole appearance and other morphological features were recovered from those abomasums cut open in the laboratory [10]. Fertilized eggs were collected from them by dissecting the worms in phosphate buffer saline (PBS). Eggs were counted per $\mathrm{ml}$ of suspension in PBS and stored at $15^{\circ} \mathrm{C}$ for further use [11].

\section{Formulation of doses of $\mathbf{N}-\mathbf{P}-\mathrm{K}$ fertilizers}

The recommended N-P-K dose for paddy cultivation in Odisha is $80-40-40 \mathrm{~kg} / \mathrm{ha}$ [12], but there exists no such organized cultivation process for Cynodon and therefore, no recommended dose is available for it. However, very low doses of N-P-K can be employed for it and keeping this in view; this experimental model was designed by taking the five doses of N-P-K for both the pasture (Table-1). Commercial fertilizers such as urea (N-46\%), single super phosphate (SSP) (P-16\%), and muriate of potash (MOP) (K-60\%) were used here. Based on the doses, the requirement of urea $(\mathrm{N})$, SSP $(\mathrm{P})$, and MOP $(\mathrm{K})$ for area $1 \mathrm{~m} \times 1 \mathrm{~m}$ were calculated (Table-1), and those were added with tap water $(100 \mathrm{ml})$ to form solution for pasture application.

\section{Experimental infestation of worm eggs on pasture}

Five parasite free experimental pasture plots of $1 \mathrm{~m} \times 1 \mathrm{~m}$ area each of paddy leaves (15-day-old) and equal number of Cynodon dactylon grass were developed (paddy plots: A, B, C, D, and E and Cynodon plots: F, G, H, I, and J) inside the experimental farm, Department of Agronomy, OUAT, Bhubaneswar. To avoid intermixing of migrated larvae, bare plots of similar size were made separating the experimental plots, and the surrounding area was fenced to prevent access of stray animals. Each plot was experimentally infested with $10 \times 10^{4}$ eggs $/ \mathrm{ml}$ PBS [13] along with the application of the test dilution of fertilizers solution (half amount as spray, another half on the soil) in September with prevailing temperature and relative humidity ranging from 23.8 to $33.7^{\circ} \mathrm{C}$ and $75-98 \%$, respectively.

\section{Pasture harvesting}

On the $10^{\text {th }}$ day of posttreatment, grass and paddy leaves weighing $100 \mathrm{~g}$ each were cut close to the soil of each plot from five places (four corners and center) in morning (7.30-10.00 A.M) when due to phototropism the vertical migration of larvae would have maximum $[14,15]$, collected and stored at $4{ }^{\circ} \mathrm{C}$ until recovery of larvae [16].

\section{Recovery, isolation, and identification of larvae from pasture}

Soaking method and Baermann technique were adopted for recovery of larvae followed by the slight modification of description of Hansen and Perry, 1994 [17]. Briefly, harvested pasture weighing $100 \mathrm{~g}$ each from five places of all plot were kept in a gauze bag (pores size: $1.5 \mathrm{~mm} \times 1.5 \mathrm{~mm}$ ) and was dipped in

Table-1: Estimation of N-P-K (urea, SSP, MOP) requirement for experimental plot $(1 \mathrm{~m} \times 1 \mathrm{~m})$.

\begin{tabular}{lccccc}
\hline Name of experimental plot & N-P-K dose (kg/ha) & Urea/plot (g) & SSP/plot (g) & MOP/plot (g) & Water (ml) \\
\hline T-1: A, F (control) & $0-0-0$ & 0 & 0 & 0 & 100 \\
T-2: B, G & $10-05-05$ & 2.17 & 3.13 & 0.84 & 100 \\
T-3: C, H & $20-10-10$ & 4.34 & 6.25 & 1.67 & 100 \\
T-4: D, I & $40-20-20$ & 8.68 & 12.5 & 3.34 & 100 \\
T-5: E, J & $80-40-40$ & 17.36 & 25.00 & 6.68 & 100 \\
\hline
\end{tabular}

$\mathrm{SSP}=$ Single super phosphate, $\mathrm{MOP}=$ Muriate of potash 
bucket having $5 \mathrm{~L}$ of water and $2.5 \mathrm{ml}$ of TWEEN ${ }^{\circledR} 20$ detergent (M/S Sigma-Aldrich India, Kolkata, India) at recommended concentration $(0.05 \% \mathrm{v} / \mathrm{v})$. The bags were kept in the bucket such that bottom of the bucket did not touch it. Within $3 \mathrm{~h}$ of the process, for proper rinsing, the bags were raised several times inside the bucket.

Then, the bags were left soaking overnight, removed and rinsed with fresh tap water into the bucket for 4 times. The buckets were kept undisturbed for $1 \mathrm{~h}$ to form sediment and the supernatant transferred to $500 \mathrm{ml}$. Then, the sediment was passed through a kitchen tea strainer to remove large grass particles and decanted to $1 \mathrm{~L}$ volume. This volume was passed through Baermann apparatus of without screen for $1 \mathrm{~h}$. The sediment $(30-40 \mathrm{ml})$ in the rubber tubing of Baermann apparatus was then collected into a test tube, centrifuged at $2000 \mathrm{rpm}$ for $3 \mathrm{~min}$ and kept at $4^{\circ} \mathrm{C}$ for $1 \mathrm{~h}$. The above supernatant was again concentrated to $10 \mathrm{ml}$. After proper mixing from $10 \mathrm{ml}$ sample, three $1 \mathrm{ml}$ aliquot samples were taken and examined under compound microscope after iodine staining. All the $\mathrm{L}_{3} H$. contortus larvae were identified and counted [10].

\section{Determination of pasture dry matter (DM) and count- ing of number of larvae per $\mathbf{k g}$ DM}

After larval recovery, the DM of each 100 g pasture was determined following standard laboratory procedure [18]. The number of larvae recovered from the pasture of each $100 \mathrm{~g}$ was calculated by taking $200 \mu \mathrm{l}$ from each $1 \mathrm{ml}$ suspension. Then average number of larvae for $200 \mu \mathrm{l}$ was counted to determine the number of larvae per $10 \mathrm{ml}$. This determined number of larvae was present in the pasture of $100 \mathrm{~g}$. The estimated number of larvae recovered from $1 \mathrm{~kg}$ of dry grass and dry paddy leaves each was calculated using the formula suggested by Krecek et al., 2004 [19].

Number of larvae recovered per $1 \mathrm{~kg} \mathrm{DM}=$ Number of larvae counted in $100 \mathrm{~g}$ pasture

Dry weight of the $100 \mathrm{~g}$ pasture

For better understanding $\mathrm{L}_{3}$ recovery was expressed as percent compared to $\mathrm{L}_{3}$ recovery in control plots considered as $100 \%$.

\section{Statistical analysis}

The data obtained for a number of larvae per $\mathrm{kg}$ DM of pasture with respect to different doses of N-P-K fertilizers were analyzed for significance by ANOVA. The means were compared by DMRT using SPSS program version 16.

\section{Results and Discussion}

The average recovered population of $\mathrm{L}_{3}$ of $H$. contortus per $\mathrm{kg} \mathrm{DM}$ varied significantly $(\mathrm{p}<0.05)$ between the paddy leaves $(5933.57 \pm 22.718)$ and Cynodon grass (4861.00 \pm 22.718$)$ (Figure-1). The tallness, more herbage of paddy leaves might help egg and larval establishment due to shade and moisture, so more larval population found as compared to Cynodon grass.

However, Cynodon is a creeping grass which creeps along the ground, so there may be more exposure to sun ray causing more death of eggs by desiccation. The present findings were akin to the earlier researchers, who observed that the different microclimates produced by the existence of different morphological and biological features among forage species affected survival and establishment of larvae [20,21].

On comparison of different doses and their impacts on different pasture revealed that for control (T-1, 0-0-0 kg/ha N-P-K), the mean $\mathrm{L}_{3}$ recovery per kg DM of paddy $(19,512.7 \pm 50.80,100 \%)$ was more than that of Cynodon grass $(16,540.9 \pm 50.80,100 \%)$, so significant difference $(p<0.05)$ was found between them. Larvae recovery per $\mathrm{kg}$ DM for different pastures were in decreasing order: T-2 of paddy $(6981.33 \pm 50.80$, $35.77 \%)$, T-2 of Cynodon (5545.38 $\pm 50.80,33.52 \%$ ), T-3 of paddy $(3173.78 \pm 50.80,16.26 \%)$, and T-3 of Cynodon $(2218.72 \pm 50.80,13.41 \%)$ which showed significant variation $(\mathrm{p}<0.05)$ among each other (Table-2). So increasing in the N-P-K concentration resulted in significant $(\mathrm{p}<0.05)$ inhibition in egg hatching as well as larval development. In T-4 and $\mathrm{T}-5$ of both pasture, the average number of recovery of larvae was nil implied no significant difference ( $p>0.05$ ) which indicated that when the N-P-K dose approached to $40-20-20 \mathrm{~kg} / \mathrm{ha}$ or more than that, complete embryonic mortality (acts as larvicidal) occurred. It has been reported that larvae recovery percentage were $19.7,4.8,1.2$, and 0 at a dose rate of urea 27.17,

Table-2: Effect of N-P-K doses on mean population of $L_{3}$ recovered from pastures.

\begin{tabular}{|c|c|c|c|c|}
\hline $\begin{array}{l}\text { N-P-K in different } \\
\text { doses ( } \mathrm{kg} / \mathrm{ha})\end{array}$ & $\begin{array}{l}L_{3} \text { recovery per } \\
\text { kg DM of paddy }\end{array}$ & $\begin{array}{c}\text { Percentage relative } \\
L_{3} \text { recovery per } k g \\
\text { DM of paddy }\end{array}$ & $\begin{array}{c}\mathrm{L}_{3} \text { recovery per } \\
\mathrm{kg} \text { DM of Cynodon } \\
\text { dactylon }\end{array}$ & $\begin{array}{c}\text { Percentage relative } \mathrm{L}_{3} \\
\text { recovery per kg DM of } \\
\text { Cynodon dactylon }\end{array}$ \\
\hline 0-0-0 (T-1), control, $\mathrm{n}=10$ & $19512.7 \pm 50.80^{a}$ & 100 & $16540.9 \pm 50.80^{b}$ & 100 \\
\hline $10-05-05(T-2), n=10$ & $6981.33 \pm 50.80^{c}$ & 35.77 & $5545.38 \pm 50.80^{d}$ & 33.52 \\
\hline $20-10-10(T-3), n=10$ & $3173.78 \pm 50.80^{e}$ & 16.26 & $2218.72 \pm 50.80^{f}$ & 13.41 \\
\hline $40-20-20(T-4), n=10$ & $0 \pm 50.80^{g}$ & 0 & $0 \pm 50.80^{g}$ & 0 \\
\hline $80-40-40(T-5), n=10$ & $0 \pm 50.80^{g}$ & 0 & $0 \pm 50.80^{g}$ & 0 \\
\hline SEM & 50.80 & & 50.80 & \\
\hline
\end{tabular}

Means with different superscripts differ significantly $(p<0.05)$ from each other in a row or a column. DM=Dry matter, SEM $=$ Standard error of mean 


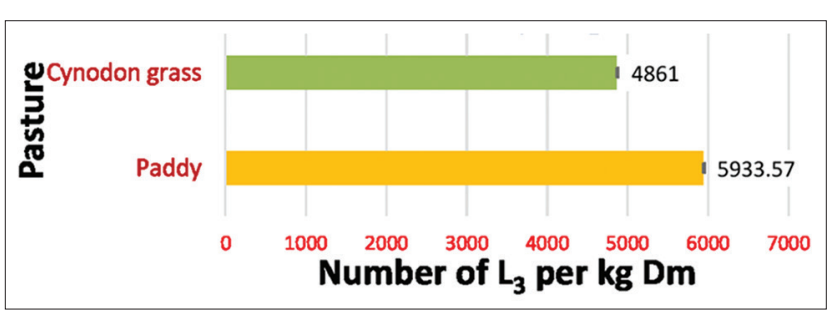

Figure-1: Effect of pastures on mean population of $L_{3}$ recovered per kg dry matter.

$54.35,108.70$, and $217.40 \mathrm{~kg} / \mathrm{ha}$, respectively [13]. Furthermore, inhibition of egg hatching of $\mathrm{H}$. contortus was most effective at 15:15:75 kg/ha N-P-K [22].

Production of toxic products such as ammonia [23-25], nitrates, and nitrites [26] from urea caused parasitic larval mortality. When larvae were exposed to fertilizers, change in osmotic pressure triggered water loss from larval cells leading to cell death [26]. Alteration of $\mathrm{pH}$ of soil and salinity due to urea or phosphorus fertilizer had adversely affected egg hatching and larval development in H. contortus [27] along with in root-knot nematodes Meloidogyne javanica and Meloidogyne incognita [28]. In other studies, urea might be lethal for juvenile, immature and mature earthworm of Eisenia foetida, by the mechanism of skin infiltration [29] and also toxic for filarial vector mosquito, Culex pipiens [30]. Some investigators observed that inorganic fertilizer (N-P-K) had potential to suppress cereal cyst nematode, Heterodera avenae population [31] as well as root-knot nematode population [32-36].

It was observed that reproduction and infectivity of entomopathogenic nematodes could be checked by N-P-K fertilizer and potassium nitrate application [37]. The inhibition of hatching of $H$. contortus eggs due to fertilizer action might be as a result of disturbance in the secretion or inactiveness of different enzymes present in the eggs for the hatching to occur [38]. Furthermore, some possible mechanism was involved to release various toxic metabolites or certain free radicals from the fertilizers since fertilizers are the potent generator of free radicals which were responsible for blocking the active metabolic process of egg hatching and their subsequent development [39]. Urea, potash, N-P-K fertilizer hindered hatching, larval development and survival of Aedes aegypti by alteration of $\mathrm{pH}$, interruption in nervous transmission, conductivity, and total dissolved solid of parasitic developmental stages [40,41].

In addition, the inhibition of development of parasite at higher doses of N-P-K fertilizers observed in this study might be due to their potency at higher doses. Combined dose of N-P-K used, in our study might have acted synergistically for more effective control in the development of larvae. Since N-P-K fertilizer in recommended dose is commonly used in agricultural practices to increase crop yield through enhanced availability of macronutrients, it can be safely recommended for use on pasture. However, available literature does not reveal harmful effects of N-P-K on normal microfauna of the environment.

\section{Conclusion}

It is concluded that administration of N-P-K fertilizers at proper dose will result in significant decrease in worm burden of $H$. contortus in pasture infectivity to grazing animals. The recovery of third stage larvae population of $H$. contortus was found to vary with pasture species.

\section{Authors' Contributions}

TKR, MRP, BM, and KKS designed the experiment. TKR and MRP carried out the experimental work. TKR, MRP, BM, KKS, MD, AH, and TM were involved in scientific discussion and analysis of the data. TKR, BM, KKS, drafted and revised the manuscript. All authors read and approved the final manuscript.

\section{Acknowledgments}

The authors are thankful to the Hon'ble ViceChancellor, OUAT, Bhubaneswar, Odisha, for providing necessary facilities to conduct the experiment. The financial assistance provided by the university was utilized to conduct the research.

\section{Competing Interests}

The authors declare that they have no competing interests.

\section{References}

1. Sharma, N., Singh, V. and Shyma, K.P. (2015) Role of parasitic vaccines in integrated control of parasitic diseases in livestock. Vet. World, 8(5): 590-598.

2. Badran, I., Abuamsha, R., Aref, R., Alqisi, W. and Alumor, J. (2012) Prevalence and diversity of gastrointestinal parasites in small ruminants under two different rearing systems in Jenin district of Palestine. An Najah Univ. J. Res., 26: 1-18.

3. Negasi, W., Bogale, B. and Chanie, M. (2012) Helminth parasites in small ruminants: Prevalence, species composition and associated risk factors in and around Mekelle town, Northern Ethiopia. Eur. J. Biol. Sci., 4(3): 91-95.

4. Torres-Acosta, J. and Hoste, H. (2008) Alternative or improved methods to limit gastro-intestinal parasitism in grazing sheep and goats. Small Rumin. Res., 77(2): 159-173.

5. Calvete, C., Ferrer, L., Lacasta, D., Calavia, R., Ramos, J., Ruiz-de-Arkaute, M. and Uriarte, J. (2014) Variability of the egg hatch assay to survey benzimidazole resistance in nematodes of small ruminants under field conditions. Vet. Parasitol., 203(1): 102-113.

6. Stromberg, B.E. (1997) Environmental factors influencing transmission. Vet. Parasitol., 72: 247-264.

7. Das, M., Deka, D.K., Islam, S., Sarmah, P.C. and Bhattacharjee, K. (2016) Gastrointestinal nematode larvae in the grazing land of cattle in Guwahati, Assam. Vet. World, 9(12): 1343-1347.

8. Perry, B.D., Randolph, T.F., Mc Dermott, J.J., Sones, K.R. and Thoronton, P.K. (2002) Investigating in Animal Health Research to Alleviate Poverty. International Livestock Research Institute, Nairobi, Kenya. p148.

9. Muniz-Lagunes, A., Gonzalez-Garduno, R., LopezArellano, M.E., Ramirez-Valverde, R., Ruiz-Flores, A., García-Muniz, G., Ramirez-Vargas, G., Mendoza De Gives, P. and Torres-Hernandez, G. (2015) Anthelmintic resistance in gastrointestinal nematodes from grazing beef 
cattle in Campeche state, Mexico. Trop. Anim. Health Prod., 47(6): 1049-1054.

10. Soulsby, E.J.L. (1982) Helminths, Arthropods and protozoa of Domesticated Animals. $7^{\text {th }}$ ed. The English Book Society and Bailliere Tindall, London.

11. Khatun, F., Begum, N., Akter, S. and Mondal, M.M.H. (2013) In vitro study of environmental and nutritional factors on the hatching and development of eggs of $H$. contortus. Bangladesh Vet., 30(1): 1-9.

12. OUAT. (2014) Annual Report 2013-14 No. 751 003. Orissa University of Agriculture and Technology Bhubaneswar. p14.

13. Swarnkar, C.P., Singh, D., Khan, F.A., Bagwan, P.S.K. and Dubey, S.C. (2002) Effect of urea application on pre-parasitic stages of $H$. contortus and its role in reducing pasture infectivity. J. Vet. Parasitol., 16(1): 23-26.

14. Camuset, P. (1994) Epidemiologie des strongyloses: Parasitisme des bovins. Bull. GTV, 41: 27-42.

15. Araujo, F.B. (2009) Control of gastrointestinal nematodes of sheep using the nematophagous fungus Duddingtonia flagrans. In: Dissertation in Animal Parasitology. Department Veterinary Medicine, Se-tor of Agricultural Sciences, Federal University of Parana, Curitiba. p115.

16. Sweeny, J.P.A., Ryana, U.M., Robertson, I.D., Niemeyerc, D and Huntc, P.W. (2012) Development of a modified molecular diagnostic procedure for the identification and quantification of naturally occurring strongylid larvae on pastures. Vet. Parasitol., 190: 467-481.

17. Hansen, J.W. and Perry, B. (1994) The Epidemiology, Diagnosis, and Control of Helminth Parasites of Ruminants. International Laboratory for Research on Animal Diseases, Nairobi, Kenya. p171.

18. Anonymous. (2012) Using a Microwave Oven to Test Moisture Content of Forage, Crop Watch. University of Nebraska-Lincoln, Institute of Agriculture and Natural Resources, USA.

19. Krecek, R.C. and Maingi, N. (2004) Comparison of two techniques used for the recovery of third-stage strongylid nematode larvae from herbage. Vet. Parasitol., 122: $233-243$

20. Carneiro, R.D. and Amarante, A.F.T. (2008) Seasonal effect of three pasture plants species on the free-living stages of H. contortus. Arq. Bras. Med. Vet. Zootec., 60: 4.

21. Heckler, R.P. and Borges, F.A. (2016) Climate variations and the environmental population of gastrointestinal nematodes of ruminants. Nematoda, 3: e012016.

22. Agarwal, R., Singhal, K.C. and Varshney, K.G. (1991) Role of fertilizers in the control of $H$. contortus eggs to infective larvae in the charcoal and different soils. Indian Vet. Med. J., 15(2): 88-89.

23. Walker, J.T. and Post, A. (1969) Reduction of lesion nematode population by decomposing nitrogenous amendments. Phytopathology, 59: 1055.

24. Mankau, R. and Mankau, S.K. (1975) The effect of $\mathrm{NH}_{4}^{+}$ concentration on selected nematodes in vitro. Nematropica, 5: 25 .

25. Foulk, D. (2013) Parasite Control is an Important Component of All Equine Health Care Programs. Think Like a Parasite - Managing Resistant Parasites in Horses, Penn State Extension. http://extension.psu.edu/animals/ equine/parasite-project/think-like-a-parasite-managing-re- sistant-parasites-in-horses. Accessed on 24-02-2017.

26. Siddique, I.A. and Taylor, D.P. (1970) Histopathogenesis of galls induced by Meloidogyne naasi in wheat roots. $J$. Nematol., 2: 239-247.

27. Iqbal, Z., Munir, A.M. and Khan, M.N. (2000) Effect of urea on the development and survival of $H$. contortus eggs and larvae. Int. J. Agric. Biol., 3: 192-194.

28. Habash, S. and Al-Banna, L. (2011) Phosphonate fertilizers suppressed root knot nematodes Meloidogyne javanica and M. incognita. J. Nematol., 43(2): 95-100.

29. Rai, N., Ashiya, P. and Rathore, D.S. (2014) Comparative study of the effect of chemical fertilizers and organic fertilizers on Eisenia foetida. Int. J. Innov. Res. Sci. Eng. Technol., 3(5): 12991-12998.

30. Olayemi, I.K., Maduegbuna, E.N., Ukubuiwe, A.C. and Chukwuemeka, V.I. (2012) Laboratory studies on developmental responses of the filarial vector mosquito, Culex pipiens pipiens (Diptera: Culicidae), to urea fertilizer. J. Med. Sci., 12(6): 176.

31. Al-Hazmi, A.S. and Dawabah, A.A.M. (2014) Effect of urea and certain NPK fertilizers on the cereal cyst nematode (Heterodera avenae) on wheat. Saudi J. Biol. Sci., 21(2): 191-196.

32. Abolusoro, S.A., Abolusoro, P.F., Mathew, F.O. and Izuogu, N.B. (2013) Effects of organic and inorganic manures on the growth attributes of root-knot nematode (Meloidogyne incognita) infected Ethopian egg plant (Solanum aethiopicum). World J. Agric. Res., 1(6): 104-107.

33. Karajeh, M.R. and Al-Nasir, F. (2014) Field utilization of nitrogen fertilizers for controlling root - Knot nematode and improving growth and yield of cucumber. Int. J. Agric. Forestry, 4(1): 34-40.

34. El-Nehal, S. and Abdel-Kader, M.M. (2014) Integration of urea fertilizer and Trichoderma harzianum for controlling Rhizoctonia solani root rot disease of lupine under field conditions. Int. J. Eng. Innov. Technol., 4(2): 213-217.

35. Shraf, R., Abbas, H. and Akhtar, A. (2014) Combined effect of biofertilizers and fertilizer in the management of Meloidogyne incognita and also on the growth of red kidney bean (Phaseolus vulgaris). Int. J. Plant Pathol., 5: 1-11.

36. Ramezani, H. and Khaniki, G.B. (2015) Evaluation efficacy of fertilizer and bio-agents on field pea against root-knot nematode. Res. J. Fish. Hydrobiol., 10(9): 195-197.

37. Bednarek, A. and Gaugler, R. (1997) Compatibility of soil amendments with entomopathogenic nematodes. J. Nematol., 29(2): 220-227.

38. Munir, M.A., Iqbal, Z. and Khan, M.N. (2001) In vitro effects of sodium chloride and calcium carbonate on the development and survival of $H$. contortus. Int. J. Agric. Biol., 3: 125-128.

39. Sarma, A.D., Mallick, A.R. and Ghosh, A.K. (2010) Free radicals and their role in different clinical conditions: An overview. Int. J. Pharm. Sci. Res., 1(3): 185-192.

40. Kumar, P., Ramarajan, S., Radha, M. and Murugesan, A.G. (2015) Effect of inorganic fertilizers on mortality and ovicidal action of dengue vector, Aedes aegypti L. (Diptera: Culicidae). Int. J. Mosq. Res., 2(4): 36-42.

41. Darriet, F. (2016) An anti-mosquito mixture for domestic use, combining a fertiliser and a chemical or biological larvicide. Pest Manage. Sci., 72(7): 1340-1345. 